\title{
Volcanism and seismicity in the Indo-Australian seismic belt: manifestations of intraplate tectonics $\left({ }^{*}\right)$
}

\author{
P. HÉDERVÁRI
}

Received on March 25 th, 1978

\section{ABSTRACT}

Disregarding the mid-oceanic ridges, the oceanic part of the IndoAustralian Seismic Belt is the longest, seismically active zone in the world-ocean. It begins west of Ceylon and runs towards Australia. The oceanic part does not show any correlation with seismologically important submarine features, such as transform faults, rift valleys or oceanic trenches. On the basis of the distribution of earthquake-epicenters the author supposes that the belt does not end at the westernmost coast of Australia but penetrates the continent and can be detected as far as south of Tasmania (Fig. 1). The length of the belt as a whole thus is some $11800 \mathrm{~km}$ out of which the length of its occanic part measures about $6500 \mathrm{~km}$, which is much longer than an oceanic trench area or the island arc, associated with it. The medium width of the belt is $1300 \mathrm{~km}$. All the shocks are of shallow origin.

The belt is characterized by a very mild volcanism; three submarine eruptions are known from the volcanological literature and two further

(*) International Research Group on Terrestrial and Cosmic Phisics Contribution No. 13/78/IRGTCP.

(**) H 1023, Budapest II. Arpad fejedlem utja 40-41, Hungary. 
submarine eruptive centers are indicated on a map issued by Soviet authors Kanaev and Turko. No other submarine volcanic eruptions are known from the Indian Ocean. From the point of view of seamounts and other submarine volcanic features, the oceanic part of the belt is the most densely populated zone in the Indian Ocean (Fig. 2). Its heat flow anomalies are similar to that of the mid-occanic ridge of the Indian Ocean and almos all the higher heat flow values of Australia and Tasmania were observed within the contnental part of the belt. The maximum heat flow value within the belt has been observed very near the place of two submarine eruptions that took place in 1879 and 1883 , respectively at about $6^{\circ} \mathrm{S}, 89^{\circ} \mathrm{E}$. This domain which is to be found in the center of the oceanic part, can be regarded to be a local spreading center which is already developed well, or to be a part of a nascent rift valley structure which will be developed within the next $25-50$ millions years (Fig. 3). If one separated the oceanic part and the continental one, the annual frequency-average magnitude relationship of earthquakes shows a rather great scatter both for the continental and oceanic parts of the belt (Fig. 4). If, on the other hand, the belt as a whole was considered, the relationship became linear practically with no scatter of the points (Fig. 5). This empirical fact demonstrates clearly that the belt as a whole must be regarded as a tectonic unit in which the earthquakes are the results of the same geologic-process (by all likelihood the birth of a rift valley system).

The strain-release graph of the belt as a whole (Fig. 6) shows that during a longer period of time the accumulation and release of seismic strains have been a uniform process. This is demostrated by the fact that the boundary-lines denoted as $a$ and $b$ are parallel with one another. We can get a similar curve for the oceanic part alone (Fig. 7), however the strain-accumulation and release in the continental part of the belt had been a uneven process.

Taking into account all the $M>4,0$ earthquakes that occurred in and near Australia in the period of 1897-1972 (Fig. 8) we can sketch the form of the continental part of the belt in more detail. In some respect this configuration differs from the simplified one which was shown in the previous drawings; we can see, namely, two curved, narrow branches as well. The main belt, however, is the same than previously.

Considering all the greater earthquakes for which $M>7,0$, that took place from 1904 through 1965, we stated that the average energy as well as the energy density in the Indo-Australian Seismic Belt were remarkably similar to that of the rift valley system of the Indian Ocean.

All the results show that we have to do with a nascent rift valley system and not with a nascent island arc as it was suggested by Sykes and was accepted previously by the present author as well. The belt considered in this study represents an excellent and interesting example for the intraplate volcanism and tectonics. 


\section{RIASSUNTO}

La parte oceanica dell'arco sismico Indo-Australiano, rispetto alle creste medio-oceaniche, è la zona sismicamente attiva più lunga dell'intero oceano. Inizia ad ovest di Ceylon e continua in direzione dell'Australia. La parte occanica non mostra alcuna correlazione con configurazioni sottomarine sismologicamente importanti, come faglie trasformi, "riftvalley system " o fosse oceaniche. In base alla distribuzione degli epicentri, l'A. ipotizza che l'arco non finisca presso la costa più occidentale dell'Australia, maentri nelc ontinente potendo probabilmente essere seguita fino a sud della Tasmania (fig. 1).

La lunghezza dell'arco è di $11800 \mathrm{~km}, 6500$ dei quali costituiscono la parte oceanica, che è molto più lunga della fossa oceanica, o dell'arco delle isole, ad essa associata. La lunghezza media dell'arco è di $1300 \mathrm{~km}$. Tutte le scosse sono superficiali. L'arco è caratterizzato da vulcanismo molto moderato: la letteratura vulcanologica riferisce su tre eruzioni sottomarine ed i sovietici Kanaev e Turko hanno riportato su una mappa due ulteriori centri eruttivi sottomarini. Non si ha notizia di altre eruzioni vulcaniche sottomarine avvenute nell'oceano Indiano.

Rispetto a tutto quanto concerne configurazioni montuose o vulcaniche sottomarine, la parte oceanica dell'arco costituisce la zona più densamente popolata dell'oceano Indiano (fig. 2). Le anomalie del flusso di calore sono simili a quelle della cresta mediana-oceanica dell'oceano Indiano e pressoché tutti i più elevati valori del flusso di calore dell'Australia e della Tasmania, sono stati osservati dentro la parte continentale dell'arco. Il massimo valore del flusso di calore dentro l'arco è stato osservato vicinissimo alla zona delle due eruzioni sottomarine del 1879 e 1883 , rispettivamente a circa $6^{\circ} \mathrm{S}, 8^{\circ} \mathrm{E}$. Questa zona, che deve trovarsi nel centro della parte oceanica, può essere considerata come un centro di propagazione locale già ben sviluppato, o come una struttura di un "nascent rift-valley system " che si svilupperà entro i prossimi $25-50 \mathrm{mi}$ lioni di anni (fig. 3). Se si separa la parte oceanica da quella continentale, la relazione frequenza annuale-magnitudo media dei terremoti mostra una dispersione piuttosto grande, sia per quanto riguarda la parte continentale che quella oceanica dell'arco (fig. 4). Se, d'altra parte, si considera l'arco come un tutt'uno, la relazione diviene praticamente lineare con nessuna dispersione dei punti (fig. 5). Questo fat to empirico dimostra chiaramente che l'arco, nel suo insieme, deve essere considerato come un'unità tettonica, nella quale i terremoti sono il risultato di qualche processo geologico.

Il grafico del rilascio di tensione nell'arco considerato come un tutt'uno (fig. 6), mostra che in un periodo più lungo di tempo l'accumulo ed il rilascio di tensioni sismiche hanno costituito un processo uniforme. 
Ciò è dimostrato dal fatto che le linee di demarcazione indicate con $a$ e $b$ sono parallele l'una all'altra.

Possiamo fornire una curva simile per la sola parte oceanica (fig. 7), tuttavia l'accumulo ed il rilascio di tensioni nella parte continentale dell'arco si è manifestato come un processo irregolare. Tenendo conto di tutti i terremoti con $M>4.0$ avvenuti in/o vicino all'Australia nel periodo 1897-1972 (fig. 8), possiamo disegnare la forma dell'arco molto più dettagliatamente. Sotto alcuni aspetti questa rappresentazione differisce da quella semplificata mostrata nei precedenti disegni; possiamo vedere, nei precedenti disegni;possiamo vedere, cioè, anche due rami curvi vicini. L'arco principale, tuttavia, è lo stesso di quello precedente.

Considerando tutti i più grandi terremoti con $M>7.0$, che avvennero dal 1904 al 1965, è stato stabilito che l'energia media, così come la densità di energia nell'arco sismico Indo-Australiano, sono state notevolmente simili a quelle del "rift-valley system " dell'oceano Indiano.

Tutti i risultati mostrano che si ha a che fare con un "nascent riftvalley system " e non con un arco nascente di isole, come era stato suggerito da Sykes ed accettato in precedenza anche dall'A. L'arco considerato in questa nota rappresenta un eccellente ed interessante esempio per il vulcanismo interplacche e la tettonica.

\section{INTRODUCTION}

Working on the construction of the maps of seismicity of the Indian Ocean the author has noticed a very interesting and conspicuous seismic zone, situation between the Andaman-Indonesian Arc and the rift valley zone of the Central Indian Ocean, and extending from a point, far west off Ceylon to at least the western shore of Australia. It became clear soon, however, that a part of this seismic zone was discussed already by Stover (1966) and Sykes (1970), respectively. Stover has pointed out that within the belt between Ceylon and the westernmost coast of Australia there were 29 great tectonic earthquakes from the beginning of this century, six of which had a Richter-magnitude of 7,0 to 7,75. The overwhelming majority of the epicentres does not show any correlation with characteristical, tectonically and seismologically important suboceanic features, such as deep oceanic trenches, rift valleys or transform faults. These kinds of tectonic features are perfectly absent from the zone con- 
sidered. Only a very few epicentres seem to be related with minor faults of the ocean-bottom; these faults penetrate the seismic belt from the south.

Sykes has put forward the very interesting idea according to which at least a part of this belt, between Ceylon and the Cocos Island in the Indian Ocean, would be a nascent island arc. This interpretation was accepted by the present author in his two preliminary papers (Hedervari, $1977 \mathrm{a}, 1977 \mathrm{~b}$ ); however there are some evidences which suggest a quite different possibility. Taking into account these evidences now the author is inclined to believe that the zone in question, called Indo-Australian Seismic Belt, is a nascent rift valley in a very primitive, early phase of its development, rather than a nascent island arc.

All shocks observed within this belt were of shallow ( $h \leqq 70 \mathrm{~km}$ ) origin. Disregarding the near environment of the true oceanic trenches and related arcs, furthermore the rift valleys and the transform faults, - the Indo-Australian Seismic Belt is the longest seismically active zone of the worldccean. Whatever is the true nature of this particular feature, it is sure that high stresses are prevailing within it, showing clearly a certain kind of deformation in an intraplate domain.

Before summarising the volcanism and other properties of the belt, it is appropiate to say briefly about its geographical position and extent.

\section{GEGGRAPHICAL POSITION AND DIMENSIONS}

Fig. 1 demonstrates the distribution of all catalogized earthquakes that occurred in the belt considered, from 1904.01.01. to 1965.12.31. Data were taken over from Gutenberg and Richter (1954) as well as Rothe (1969). According to the distribution of epicenters the seismic zone seems to be continuous, although the distribution is not uniform. The medium width of the belt is some $1,300 \mathrm{~km}$. It appears that the seismic zone does not end at the western coast of Australia but penetrates deeply the con- 


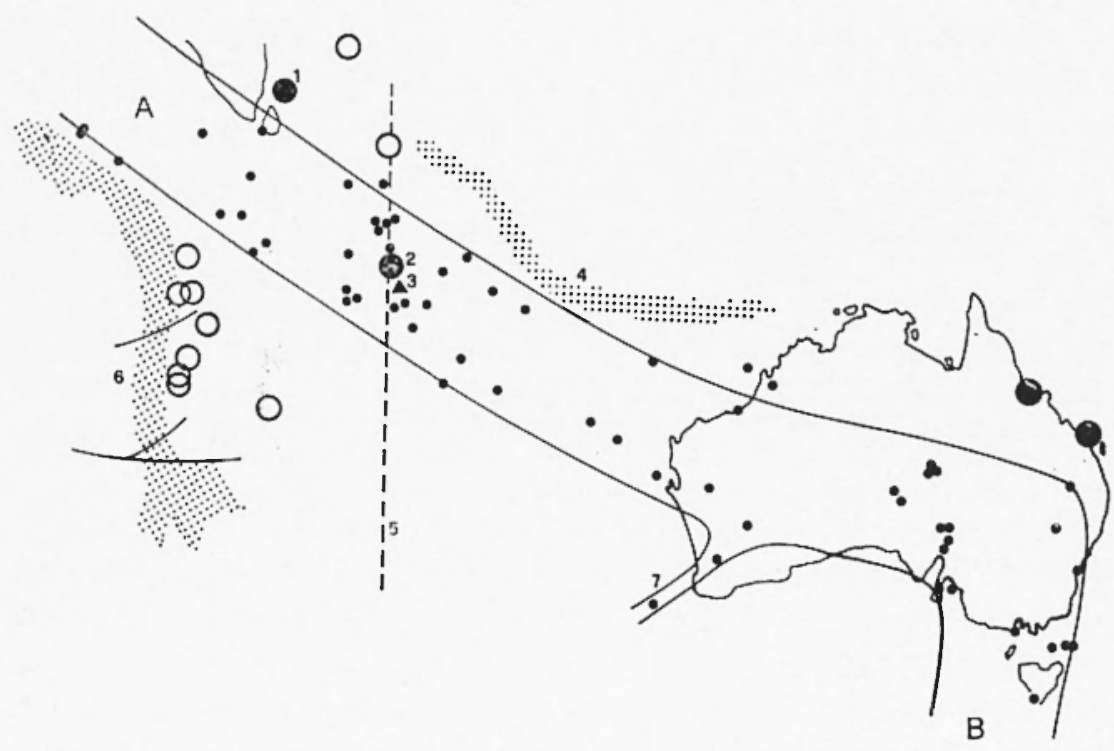

Fig. 1 - Epicentres of $M<5,5$ earthquakes within and near the Indo-Australian Seismic Belt from 1904.01.01. to 1965.12.12.31. A: the northwestern termination of the belt; $B$ : the southeastern end; 1: site of the Pondicherry submarine eruption in 1757; 2 : site of the submarine eruptions of the years 1879 and 1883, respectively; 3: the place of the "hot spot" (perhaps a local spreading centre with a heat flux value of 7,61 HFU); 4: the Andaman-Indonesian Arc; 5: axis of te Ninetyeast Ridge; 6: border-line of the midoceanic ridge; 7: a possible branch of the Indo-Australian Seismic Belt (another configuration for the same offset can be seen in Fig. 8). Empty circles: shocks outside of the mid-oceanic ridge but not belonging to the IndoAustralian Seismic Belt; double circles: earthquakes of northeastern Australia (may be the signs of a second offset, see in Fig. 8). 
tinent. At the Darling Range a narrow branch (offset) can be seen, this running towards the southwest, back again into the ocean. The most prominent property of the zone is its sharp bend in the Southern Queensland district. Here the zone changes its direction by about $90^{\circ}$ and runs towards Tasmania. According to the map of world-seismicity, compiled by Barazangi and Dorman (1969) south of Tasmania there occurred another tectonic earthquake between 1961 and 1967. By all likelihood this represents the very sharp, abrupt end of the Indo-Australian Scismic Belt. This point is denoted by letter B on the drawing enclosed. Letter A denotes the other, that is the northwestern end of the zone. The author supposed in his preliminary papers that the belt extends as far as to the mouth of the Gulf of Oman. This earlier supposition, however, must be rejected, since the seismic gap between point $A$ and the Gulf of Oman is too long. The seismic events in the Gulf of Oman, furthermore, are related to the Owen Fracture Zone. Consequently the earlier suggestion of the author, according to which the Indo-Australian Seismic Belt would be connected to the Iran-Pakistan Seismic Belts and would be their continuation, must also be regarded as obsolete.

The total length of the belt from point $A$ to $B$ is some $11,800 \mathrm{~km}$. The length of the oceanic part alone is about 6,500 $\mathrm{km}$, that is roughly three times larger than the length of a normal island arc. Regarding its medium width to be $1,300 \mathrm{~km}$, the total area amounts to $15,340,000 \mathrm{~km}^{2}$, that is the belt is much larger in area than Europe, the latter being $10,498,000 \mathrm{~km}^{2}$.

Geographically the Indo-Australian Seismic Belt can be divided into two parts: an oceanic and a continental one. We shall see later on, however, that geophysically (at least from the point of view of heat flow and seismicity) it is a tectonic unit. 
Fig. 2 - shown the distribution of seamounts and other volcanic features in the Indian Ocean as well as the oceanic part of the belt. The chart is a somewhat simplified version of the map of the seamoust, published by Kanaev and Turko (1976). The so-called block-seamounts were omitted as their volcanic nature is doubtful. The rift valley which is the site of presentday basaltic lava-flows from the mantle onto the bottom of the ccean is not indicated.

It is noteworthy that the area which is most densely populated with seamounts in the Indian Ocean can be found in the belt considered. The zone of seamounts ends very abruptly in the Arabian Sea just near point A which denotes the northwestern termination of the Indo-Austrialian Seismic Belt. South of Tasmania we can see a linear chain of seamounts which ends somewhat south of point B which signs the southeastern termination of the seismic zone.

Another, also very important fact is that the only known submarine eruptions, occurred in the Indian Ocean, outside of the rift valleys, took place either within the Indo-Australian Seismic Belt or near its northern border. We have in hand the following data (Sapper, 1927; Gutenberg and Richter, 1954; Neumann van Padang, 1963):

A mild submarine eruption took place in 1757 north of Ceylon, that is outside of the belt, however not too far from its northern border. Near the town of Pondicherry, India, an island, made up from volcanic scoria, has emerged from the sea. Approximate coordinates of the event are $12^{\circ} \mathrm{N}, 80^{\circ} \mathrm{E}$. At about $6^{\circ} \mathrm{S}, 89^{\circ} \mathrm{E}$ two eruptions occurred in historic times: the first one in 1879 and the second in 1883. In the latter's case floating pumice was seen on the spot. The site of these two eroption at $6^{\circ} \mathrm{S}, 89^{\circ} \mathrm{E}$ can be found in the interior of the belt investigated and just on the crestal zone of the Ninetyeast Ridge. In the near environment of the place of this sub- 


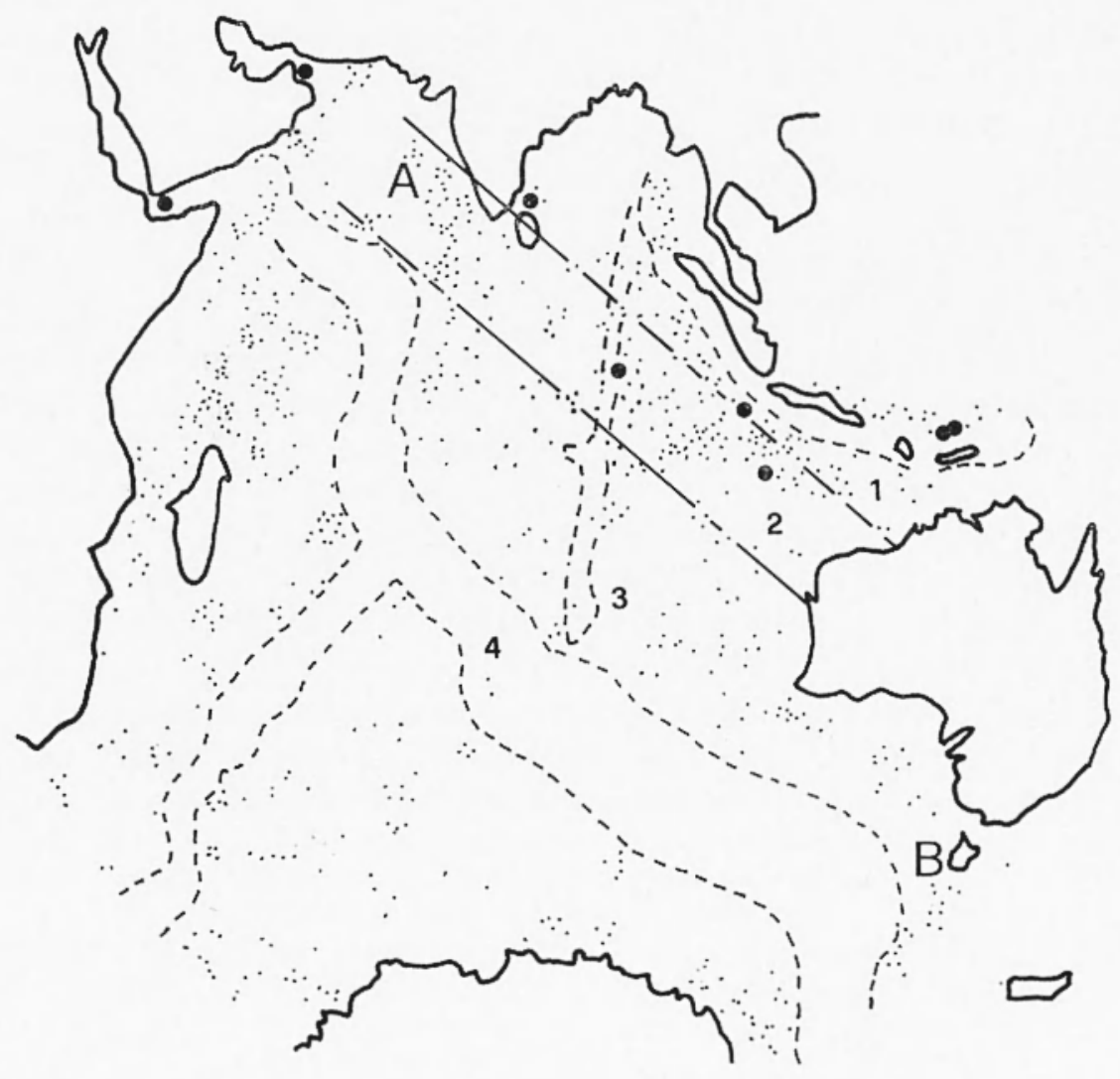

Fig. 2 - Distribution of seamounts and other volcanic features in the Indian Ocean (after Kanaev and Turko, simplified). The black circles are the sites of the submarine eruptive centres. A: the northwestern termination of the Indo-Australian Seismic Belt; B: the southeastern end; 1: Java Trench; 2: the oceanic part of the belt considered;

3: the Ninetyeast Ridge; 4: the mid-oceanic ridge. 
marine volcano the density of earthquake-epicentres is relatively high and three $M \leqq 7,1$ shocks took place here.

These facts demonstrate clearly that: 1). the Ninetyeast Ridge is not perfectly inactive tectonically as this inactivity has been pointed out by some earlier authors; and 2). the relatively active part of the Ninetyeast Ridge is that segment where this feature is intersected by the Indo-Australian Seismic Belt. This is the northern half of the Ridge. Only one shock is known from the southern end of the Ridge and no submarine eruptions took place in the southern half.

In the map of Kanaev and Turko (1976) two further sub marine eruptive sites are indicated, but without any additional data. The first of them is to be found southwest of Krakatau volcano; the second is located just south of the westernmost tip of Java. Both are oceanward off the Java Trench. The first submarine center of volcanic activity is being situated on the northern border of the Indo-Australian Seismic Belt, while the second one is within the belt. As far as we can state from the original map of Kanaev and Turko, this second submarine volcanic center may be in the proximity of Christmas Island that possesses a Lower Tertiary volcano of the atlantic suite (Van Bemmelen, 1954).

In Fig. 3 the author has constructed a map showing the highest heat flow values of the Indian Ocean. The data were taken over from Lee and Clark (1966) as well as from Simmons and Horai (1968), respectively .Some additional data were taken over from a computerized list issued by the Lamont-Doherty Geoogical Observatory (year of publication is not indicated). Over oceanic areas all values of heat flow were demonstrated provided that the value was at least 3,00 heat flow units $\left(\mathrm{HFU}=10^{-6}\right.$ cal $\mathrm{cm}^{-2} \mathrm{sec}^{-1}$ ) or greater. On the area of Australia and Tasmania the lower limit was chosen as 2,00 HFU.

This map shows a very important fact. In the Indian Ocean there are only two belts within which the heat flow reaches high values well above the world-average. The first, as it can be expected, is the rift valley along the median axis of the midoceanic ridge. The second is the Indo-Australian Seismic Belt! 


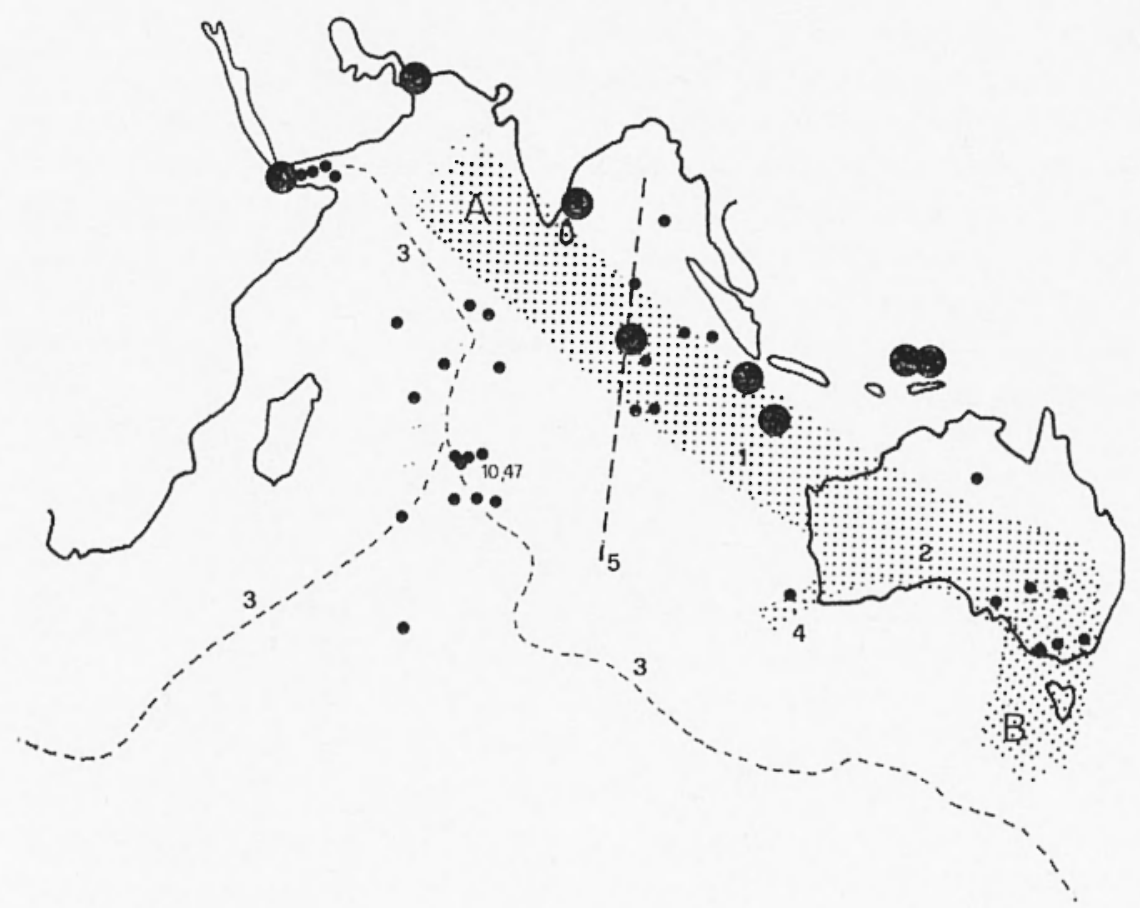

Fig. 3 - Places of points in the Indian Ocean over which abnormally high heat flow values were observed. In oceanic areas all values of $3.000 \mathrm{HFU}$ or greater indicated. On the area of Australian and Tasmania the lower limit was chosen to be $2.000 \mathrm{HFU}$. The two maxima are $10,47 \mathrm{HFU}$ and $7,61 \mathrm{HFU}$, respectively, the first is in the rift valley area, the second in the Indo-Australian Seismic Belt. 1: the oceanic part of the Indo-Australian Seismic Belt; 2: the continental part (simplified version; in more detail see Fig. 8); 3: axis of the mid-oceanic seismic belt (corresponding approximately to the axis of the rift valley); 4: a branch of the Indo-Australian Seismic Belt (simplified version); 5: axis of the Ninetyeast Ridge; $A$ : the northwestern termination of the Indo-Australian Seismic Belt; $B$ : the southeastern end. Large black circles show the sites of the submarine eruptive centers. Note that the majority of high heat flow values are to be found either in the area of the mid-oceanic ridge near the rift valley, or within the Indo-Australian Seismic Belt.. There are only three points well outside of these zones. 
As regards the continental part of this belt, the high heat flow values over the area of Australia (and Tasmania as well) are to be found again within the seismically most active zone.

The largest value $(10,47 \mathrm{HFU})$ is to be found just in the triple junction of the mid-oceanic ridge, at $21^{\circ} 59^{\circ} \mathrm{S}, 68^{\circ} 29^{\prime} \mathrm{E}$ (Simmons and Horai, 1968). The second largest value in the Indian Ocean as a whole $(7,61 \mathrm{HFU})$ is to be found within the Indo-Australian Seismic Belt, at $7^{\circ} 42^{\prime} \mathrm{S}, 90^{\circ} 02^{\prime} \mathrm{E}$ (see the 3rd line of the Lamont-paper, mentioned above, in the column of "Indian Ocean »).

This particular " hot spot " - which can be regarded either to be a small, independent, local spreading center or to be a well-developed part of a nascent rift valley structure - is to be found very near the submarine volcano, erupted in 1879 and 1883 , respectively. The distance between the site of this volcanic center and the place where the exceptionally high heat flow value was observed is as low as about $200 \mathrm{~km}$. The existence of this particular spot on the crest of the Ninetyeast Ridge and very near a weakly active, submarine volcano demonstrates again that in the case of this ridge we can not speak about a perfectly inactive tectonic feature.

\section{SEISMOLOGICAL PROPERTIES.}

In one of the preliminary papers (Hedervári, 1977 b) two graphs were presented which demonstrated the annual frequency - (average) Richter-magnitude relationship of earthquakes of the belt considered in this study. Here we show again the graphs in question. Fig. 4 . is the relationship separately for the oceanic and continental parts. We can see a relatively great scatter of the points. Fig. 5. refers to the Indo-Australian Seismic Belt as a whole, from point $\mathrm{A}$ to $\mathrm{B}$. This exhibits an almost perfectly linear distribution of the points which corresponds to a very regular frequency-magnitude relationship. Consequently the belt as a whole must be regarded to be a tectonic unit. Furthermore: one can conclude that everywhere along the whole belt the same tectonic process leads to the origin of earthquakes. 


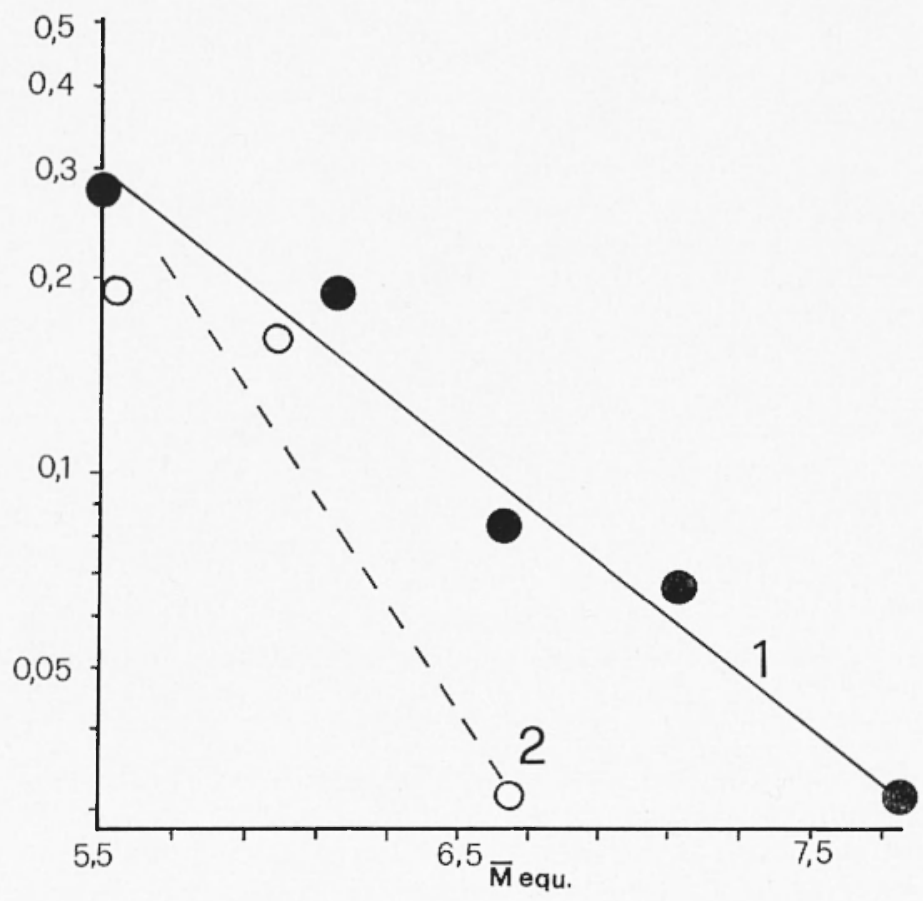

Fig. 4 - The annual earthquake (a) versus (average) Richtermagnitude $\left(M_{\text {equ }}\right)$ relationship for the oceanic part (1) and for the continental part (2) of the Indo-Australian Seismic Belt. The graph was constructed on the basis of all $M$ $\geqq 5.5$ earthquakes that took place from 1904.01.01. to 1965.12.31. The scatter of the points is rather high particularly in the case of (2). 


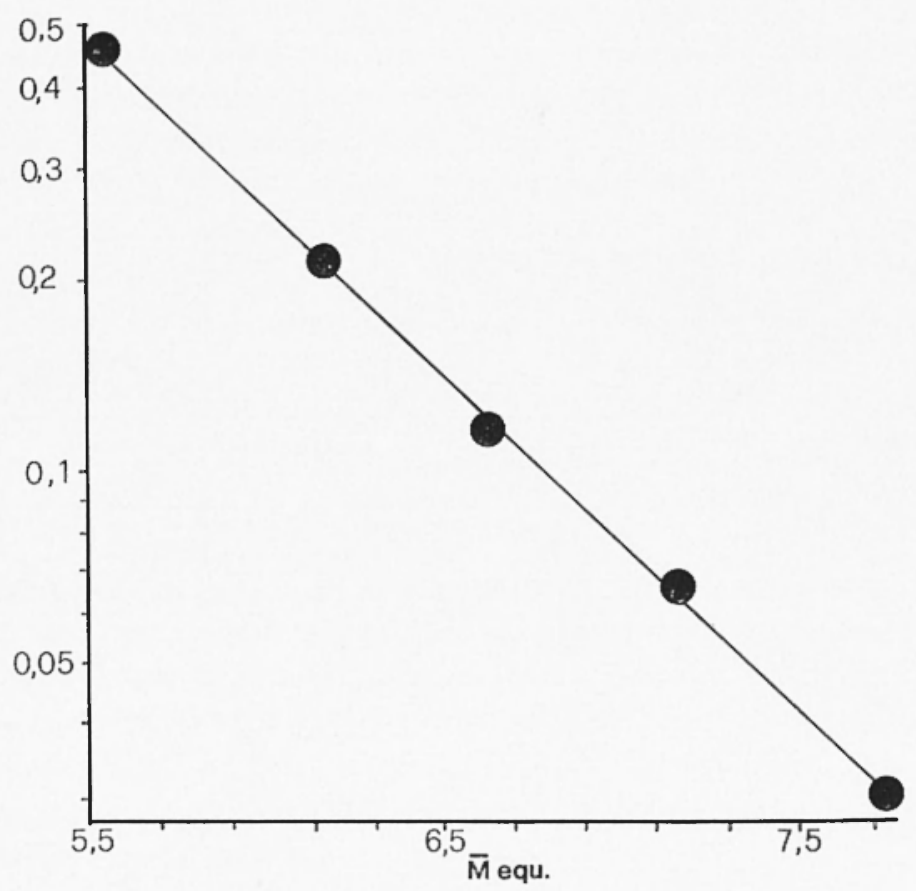

Fig. 5 - The annual earthquake frequency - average Richtermagnitude relation for the belt as a whole. The scatter of the points is perfectly insignificant. This graph shows clearly that the belt as a whole must be regarded to be a tectonic unit and the earthquakes within it are due to the same process.

Fig. 6. shows the elastic strain-release within the IndoAustralian Seismic Belt. Although there were some minor periods between 1906 and 1965, the graph, as a whole, shows a uniform accumulation and release of seismic strains which is clearly demonstrated by the fact that lines $a$ and $b$ are parallel. This property demonstrates again that the belt as a whole really is a tectonic unit. For the oceanic part alone we can 


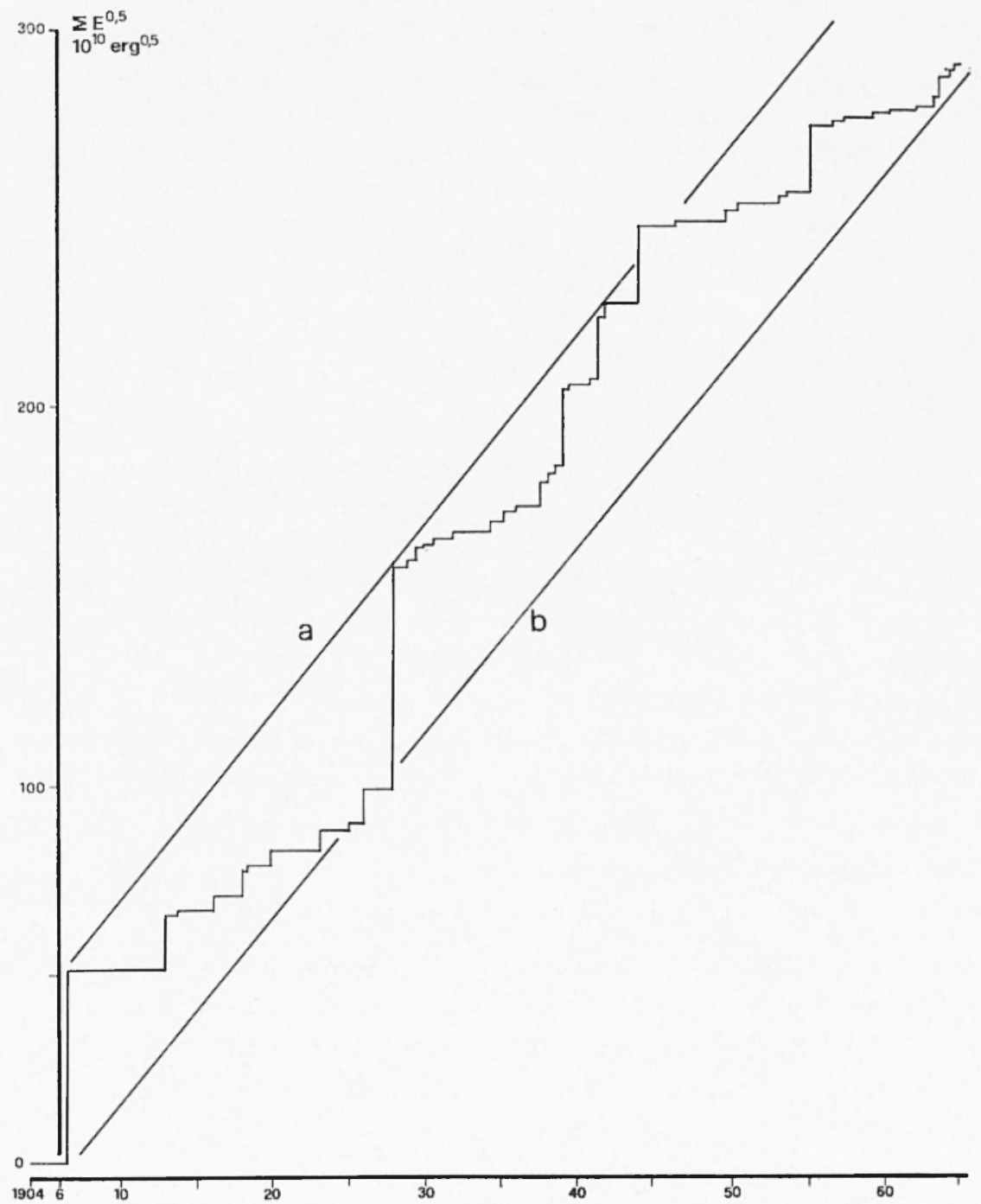

Fig. 6 - Elastic strain-release characteristics for the IndoAustralian Seismic Belt as a whole on the basis of all $M \geqq 5.5$ shocks, occurred from 1904.01.01. to 1965.12.31. As the boundary-lines ( $a$ and $b$ ) are parallel with one another, the strain-accumulation and release have been a uniform process during the time-interval investigated, in spite of the fact that there were smaller periods characterized by relatively great and small strain-release. 
get a rather similar characteristics (Fig. 7.); but for the continental part the graph shows a non-uniform accumulation and release of seismic strains (lower curve in Fig. 7.). Note that the seismic strain is proportional to the square-root of seismic energy. If the energy is $\mathrm{E}$ and is expressed in ergs, then the strain can be expressed in ergs ${ }^{0,5}$ units and is denoted by $E^{05}$.

ThE NATURE OF THE INDO-AUSTRALIAN SEISMIC BELT

There may be two - quite opposite - explanations for the nature of the belt. 1). It is a nascent island arc between Ceylon and Australia, as it was proposed by Sikes (1970) and was previously accepted by the present author as well. 2). It is a nascent rift valley structure, which is at present the supposition of the writer. It is clear that suppostion 1). is valid only for the oceanic part alone, while supposition 2). refers to the belt as a whole, taking into account the possibility that the rift valley can penetrate continental areas (e.g. Iceland, East Africa and even the Baikal region).

The main arguments of Sykes in favour of supposition 1), are summarized as follows:

a) The approximate length of the zone (between Ceylon and the Cocos Island) is similar to the Andaman and other island arcs.

b) The belt is much wider than the seismic belt of the oceanic ridge crest area, and similar to the width of the shallow seismic zones in island arcs.

c) Linear topographic elevations are absent within the belt, while such long bulges are characteristical to the rifts in East Africa (and to the mid-oceanic ridge-systems as well), therefore "the Ceylon-Cocos zone is not a nascent spreading ridge " (Sykes, 1970, p. 5050).

d) The high percentage of large (shallow) earthquakes may be the consequence of the formation of new faults on the ocean-bottom. 


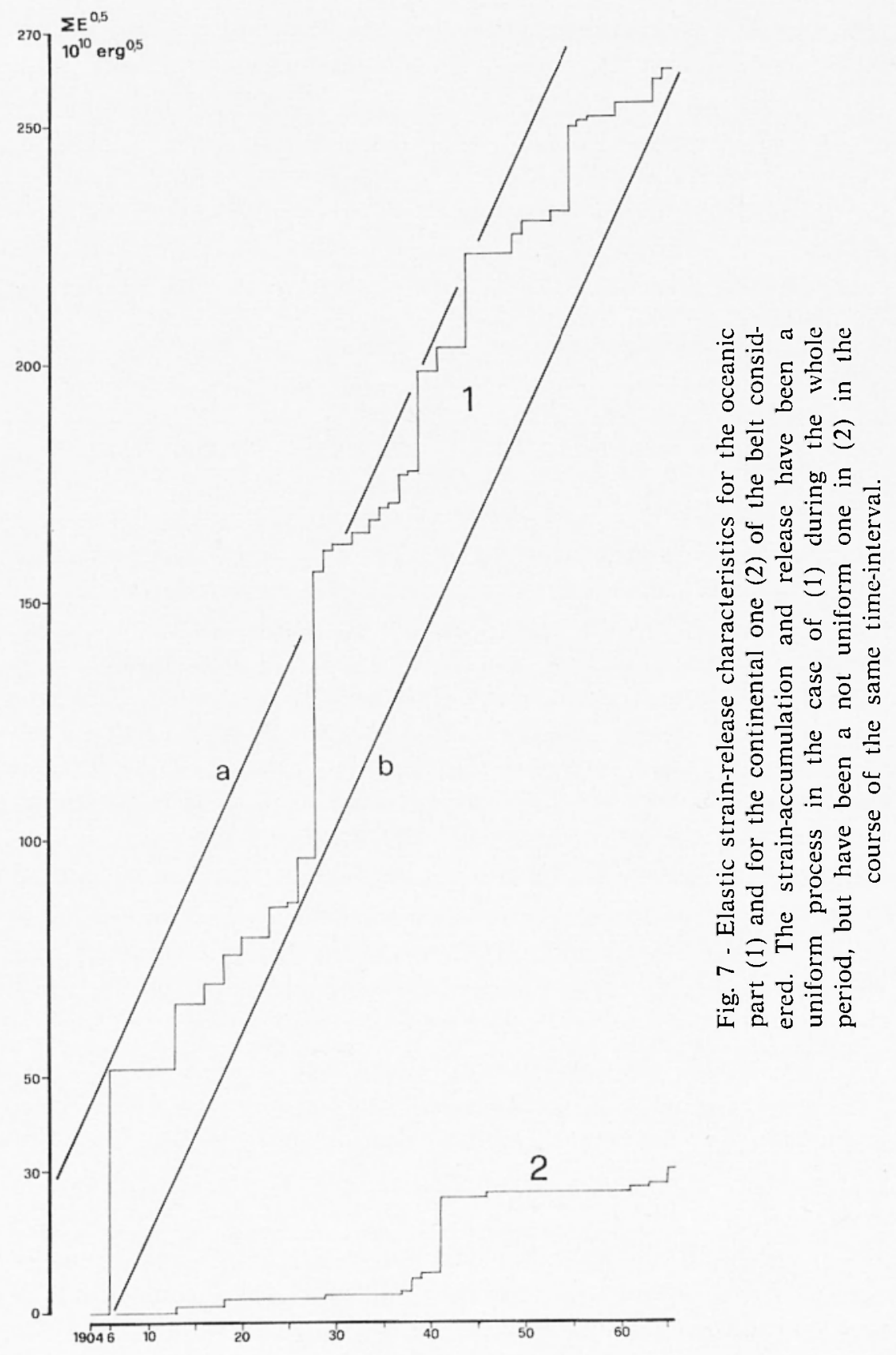


e) The earthquake-mechanism studies neither support nor refute supposition 1 ).

f) A new island arc can be developed by the migration of an older, already existing arc towards the open ocean, as the result of the development of marginal seas behind the older arc in question. This spreading is due to the extensional rifting process on the floor of the respective marginal basins. In our case such a displacement can be supposed for the AndamanIndonesian arc, due to the slow expansion of the marginal seas that are to be found continentalward of it (e.g. Java Sea, Flores Sea).

Needless to say that the present author may be mistaken; however these arguments are not too convincing for him. The counter-arguments are as follows:

a) As it was proved by the help of the pattern of heat flow anomalies and the seismological properties of the belt, it is a tectonic unit with a total length of about $11800 \mathrm{~km}$, which is much larger than the length of a normal island arc. For example, the length of the Kurile-Kamchatka Trench is $2200 \mathrm{~km}$, that of the Mariana Trench is $2550 \mathrm{~km}$, the Tonga Trench 1400 $\mathrm{km}$, the Kermadec Trench $1500 \mathrm{~km}$, etc. (Fairbridge, 1966), and the island arcs that are physically related to them have a similar length. As mentioned previously, the length of the oceanic part of the belt is about $6500 \mathrm{~km}$.

b) The width of the seismic belt associated to the midoceanic ridge of the Indian Ocean in some places reaches the value of 1000-1300 km (e.g. southwest and southeast of Madagascar, southwest of the southwestern corner of Australia).

c) The linear topographic elevations are not characteristical for incipient rift-structures at the beginning of their development. For instance the Red Sea do not possess such an elevation (ridge) but only an axial rift (see e.g. Girdler's Fig. 5 b., p. 11., 1963). The rift is the first feature while the ridge on its two sides developes only later.

d) The occurrence of large (shallow) shocks may be the result of the formation of a rift-like feature on the floor of the 
ocean, too, as such a process involves the creation of new faults along which the rift will be developed.

e) The earthquake-mechanism studies neither support nor refute supposition 2 ).

f) The author accepts the view according to which a new island arc can perhaps be developed by the migration of an older one towards the open ocean, due to the expansion of the marginal basins. In this case, however, one should expect a relatively short, say about $1500-2500 \mathrm{~km}$ long curved arc which is convex, seing from the island arc. But the Indo-Australian Seismic Belt is almost perfectly straight between Ceylon and the western coast of Australia with a slight curvature very near the shore. Here, within this short section, the belt is concave seeing from the islands of the Indonesian arc and not convex. Its general trend is by and large parallel with the strike of the rift valley of the southeastern part of the Indian Ocean.

Let us remember to the fact that the heat flow pattern of the Indo-Australian Seismic Belt is similar to that of the rift valley of the Indian Ocean. The exceptionally large heat flow value $(7,61 \mathrm{HFU})$, that was measured near the place of a submarine volcano, suggests the presence of a local spreading center. It is well-known, on the other hand that over the oceanic trenches small heat flow values were measured, usually smaller than the world-average and in the island arcs higher values of heat flow can be experienced only over the volcanic chain. It can be supposed with great certainty that these higher heat flow values inside the island arcs are the results of the existence of magma chambers within the crust. In the absence of such magma chambers (and therefore in the absence of andesitic volcanoes) such high heat flow values can not exist. Therefore the high values are due to the subduction of the oceanic lithosphere behind the trench, as thus subduction and underthrust-mechanism lead to the creation of primary magma chambers at a depth of $100 \mathrm{~km}$ or more and to the development of secondary chambers well above them, within the crust itself. Without subduction - that is in the case of a nascent island arc at the very early stage of its development - we can not 
expect the existence of high heat flow values. And because we do experienced high values within the Indo-Australian Seismic Belt, this feature can not be regarded as a nascent island arc in the proximity of which no understrusting occured as yet. But the high heat flow, which is observed within the Indo-Australian Seismic Belt, suggests the presence of hot (basaltic) mantle material near the surface, very similarly to the case of mid-oceanic ridges and particularly that of the rift valleys.

Finally it is interesting to note some further seismological facts.

The total length of the rift valley system of the Indian Ocean is some $20,500 \mathrm{~km}$. (It was measured from a point just south of South Africa throughout the triple junction east of Madagascar to the mouth of the Gulf of Aden - and, furthermore, from the triple junction to a point just south of the central part of the Great Australian Bight. The length mentioned means the length of these two sections taking together). Considering all $M \leqq 7,0$ earthquakes that took place in the Indian Ocean from 1904. January 1 to 1965 . December 31, and taking into account the modified magnitudes of a few earthquakes, given by Richter (1958) we received the following data:

\begin{tabular}{|l|c|c|}
\hline & $\begin{array}{c}\text { Indo-Australian } \\
\text { Seismic Belt }\end{array}$ & $\begin{array}{c}\text { Rift valley } \\
\text { system }\end{array}$ \\
\cline { 2 - 3 } Total energy & $12967,8 \cdot 10^{20} \mathrm{ergs}$ & $24835,9 \cdot 10^{20} \mathrm{ergs}$ \\
Average energy & $2161,3.10^{20} \mathrm{ergs}$ & $2257,8 \cdot 10^{20} \mathrm{ergs}$ \\
Energy-density & $1,10.10^{20} \mathrm{ergs} / \mathrm{km}$ & $1,21.10^{20} \mathrm{ergs} / \mathrm{km}$ \\
\hline
\end{tabular}

We can see that the average energies are very similar to one another and the energy-densities are almost exactly the same. The average energy can be calculated by dividing the total energy with the number of the events considered. According to these results the seismic energy release in the Indo- 
Australian Seismic Belt and i nthe rift valley system of the Indian Ocean was remarkably similar. This can be regarded as a further proof for the supposition 2).

All these statements (including the counter-arguments that were treated above) suggest very strongly that the Indo-Australian Seismic Belt is a nascent rift valley structure, that is a forthcoming sprending axis which will fully be developed within the next 25-50 millions years and not an island arc in the very early stage of its development - quod erat demostrandum

THE AUSTRALIAN SECTION IN MORE DETAIL.

Up to the present point the continental (Australian) part of the belt was more or less simplified since we applied the data of the greatest $(M \geqq 5,5)$ earthquakes, occurred from 1904 through 1965. We have in hand, however, a good seismological map which contains the distribution of epicenters of all $M>4,0$ earthquakes occurred from 1897 through 1972 (Denham et al., 1975). Fig. 8. shows the distribution of the epicenters on the basis of the map in question. All Australian shocks were of shallow origin, as we can find exclusively shallow earthquakes within the oceanic part of the belt as well. Only those shocks are indicated which occurred east of the $109^{\circ} \mathrm{E}$ meridian. Large circles denote earthquake for which $M>5,9$. This map permits a detailed study of the continental part of the Indo-Australian Seismic Belt. Comparing the pattern of seismicity shown in Fig. 1. with that of Fig. 8., we can state the followings:

According to Fig. 8. it may be that the belt at the western coast of Australia is wider than previously supposed on the basis of Fig. 1. Furthermore: it appears that the narrow offset at the southwestern corner of Australia is strongly curved and goes towards the Great Australian Bight. Finally, it may be that the belt has another narrow branch, too, which runs at first towards the north and then towards the northwest, along the eastern shore of the continent. The main belt, however, is the same as it was indicated in Fig. 1. 


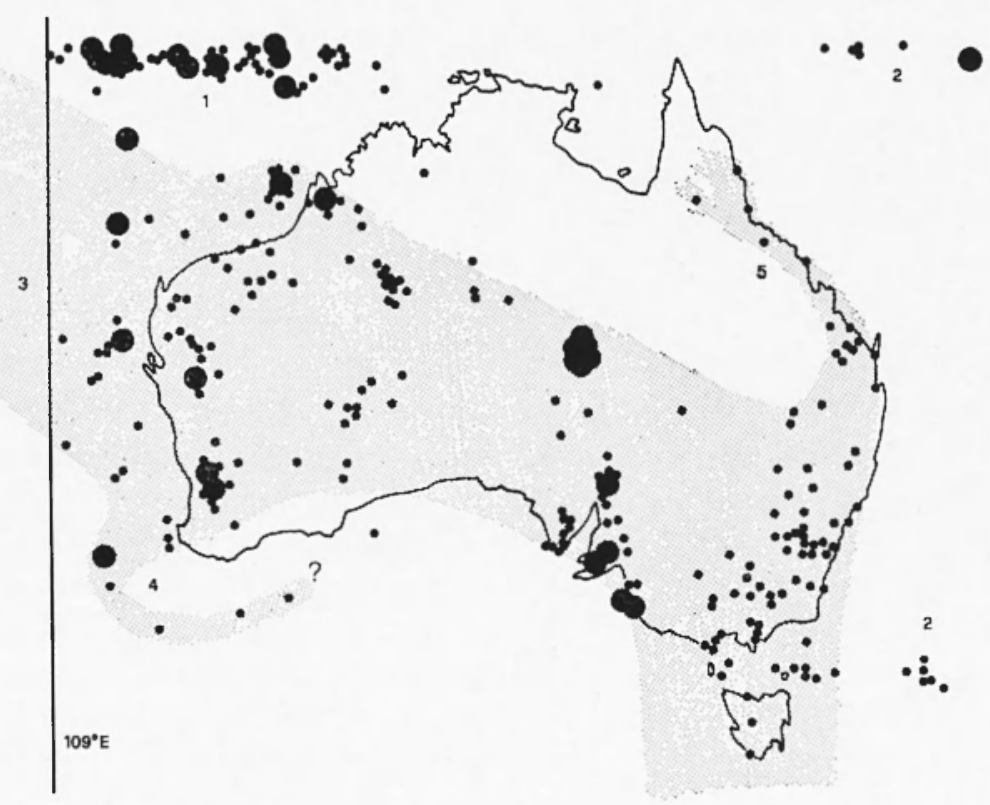

Fig. 8 - Epicentres of earthquakes with $M>40$ for the period of 1897-1972, after Denham et al. Shocks west of the $109^{\circ} \mathrm{E}$ meridian are not indicated. Large circles are epicenters of shocks for which $M>5.9$. The dotted area is a part of the Indo-Australian Seismic Belt, drawn on the basis of these earthquakes. 1: shocks belonging to the earthquake-belt of the Pacific; 3: oceanic part of the Indo-Australian Seismic Belt; 4: the curved offset mentioned in the text; 5: a possible second offeset along the eastern and northeastern shore of Australia. The pattern by and large is similar to the one which can be seen in Fig. 1., however there are certain differences as well as described in the text. 


\section{REFERENCES}

Barzangi M., Dorman I, 1969 - World Seismicity Maps. Compiled from USA Coast and Geodetic Survey, Epicenter Data, Seism. Soc. Am. Bull., $59,1$.

Bemmelen R.W. van, 1954 - Mountain Building. The Hague.

Deham D., et al., 1975 - Australian Eorthquakes (1897-1972). Seach, 6, 1-2. 1975.

FAIRBRIDGE R.W. (editor), 1966 - The Encyclopedia of Oceanigraphy. New York.

GirdLER R.W., 1963 - Geophysical Studies of Rift Valleys. In: Physics and Chemistry of the Earth, Vol. 5. Oxford.

Gutemberg B., Richitlik C.F., 1954 - Seimicity of the Earth. IInd Ed. Princeton.

Hedervari P., 1977a - Seismicity Maps of the Indian Ocean. Berida, Geosurvey Newsletter, 9, 4.

Hedervari P., 1977b - The Indo-Australian Seismic Belt. Berida, Newsletter, 9, 13.

KanaEv V.F., TURKo N.N., 1976 - Morphology and Volcanism of the Indian Ocean Floor. In: Volcanoes and Tectonosphere. Tokyo.

LeE W.H.K., CLARK S.P. Jr., 1966 - Heat Flow and Volcanic Temperature. In: Handbook of Physical Constants, Revised. Ed., Geol. Soc. Am. Mem., 97.

Neumann van Padang M., 1963 - Catalogue of the Active Volcanoes of the World, Part XVI. Arabia and the Indian Ocean, Napoli.

Ricirter C.F., 1958 - Elementary Seismology. San Francisco.

Rotrie J.P., 1969 - The Seismicity of the Earth, 1953-1965. Paris.

SAPPER K., 1927 - Vulkankunde. Stuttgart, 1968.

Simmons G., Horai K., 1968 - Heat Flow Data 2. "Journ. Geophys. Res "., 73, 20.

Stover C.W., 1966 - Seismicity of the Indian Ocean. "Journ. Geophys. Res. ", 73, 20.

Sykes L.R., 1970 - Seismicity of the Indian Ocean and a Possible Nascent Island Arc between Ceylon and Australia. "Journ. Geophys. Res.", $75,26$. 